\author{
Agata Wieczorek \\ Uniwersytet Łódzki \\ e-mail: agatka.wieczorek@interia.pl
}

\title{
AKCJE FANTOMOWE JAKO ELEMENT POLITYKI ZMIENNYCH SKŁADNIKÓW WYNAGRODZENIA W POLSKIM SEKTORZE BANKOWYM
}

\section{PHANTOM STOCK PLAN AS A VARIABLE COMPONENT OF COMPENSATION POLICY IN THE POLISH BANKING SECTOR}

DOI: $10.15611 / \mathrm{e} 21.2015 .3 .08$

JEL Classification: G34, G21, D22

Streszczenie: Nieefektywna polityka wynagradzania kadry kierowniczej najwyższego szczebla oraz podejmowanie nadmiernego ryzyka przez menedżerów w spółkach z sektora bankowego zostały uznane za jedne z głównych źródeł wybuchu ostatniego kryzysu finansowego. Doprowadziło to do pojawienia się nowych regulacji, w których zachęca się przedsiębiorstwa do uzależniania wynagrodzenia osób zarządzających od wyników osiąganych przez spółkę w długim okresie, poprzez odroczoną część płacy. Do tego celu można wykorzystać wiele różnych instrumentów finansowych, takich jak: akcje, opcje na akcje, akcje z ograniczonym prawem sprzedaży czy też coraz powszechniej stosowane akcje fantomowe. Akcje fantomowe to rodzaj planu wynagrodzenia, który upoważnia ich posiadacza do otrzymania środków pieniężnych w pewnym momencie w przyszłości. Dzięki temu, że wielkość wypłaty najczęściej powiązana jest z ceną akcji, spółka może mieć pewność, iż działania kadry kierowniczej najwyższego szczebla będą nastawione na osiąganie dobrych wyników w długim okresie. Co więcej, ten rodzaj wynagrodzenia, w porównaniu z akcjami czy opcjami na akcje, nie powoduje konieczności powiększenia kapitału zakładowego, gdyż nie wiąże się z otrzymaniem przez pracowników rzeczywistych akcji. Zalety te sprawiają że akcje fantomowe mogą się stać jednym z podstawowych elementów zmiennego wynagrodzenia. Celem artykułu jest zbadanie, czy polskie banki publiczne wykorzystują akcje fantomowe przy wynagradzaniu osób zarządzających. Zostanie zbadane, w jakim zakresie banki notowane na Giełdzie Papierów Wartościowych w Warszawie wykorzystują akcje fantomowe oraz jakie informacje na ich temat ujawniają. Analiza wykazała niewielkie zainteresowanie akcjami fantomowymi, które można tłumaczyć tym, że polskie banki publiczne dopiero od 2012 r. są zobowiązane wynagradzać menedżerów również za pomocą wynagrodzenia zmiennego odroczonego. W związku z tym część banków może być dopiero w trakcie wprowadzania takiego programu, przez co nie zdecydowała się na ujawnianie szczegółowych informacji. Przykładem mogą być Alior Bank, ING i PKO BP, które jedynie wspomniały w swoich raportach o tym instrumencie wynagradzania. Dodatkowo dziesięć banków posiadało inne długoterminowe programy mo- 
tywacyjne, co mogło je zniechęcić do korzystania również z tej formy wynagrodzenia. Akcje fantomowe jako element zmiennego wynagrodzenia kadry kierowniczej najwyższego szczebla w polskim sektorze bankowym można uznać za nowy pomysł, biorąc pod uwagę fakt, iż pierwsze informacje o ich wykorzystaniu pojawiły się dopiero w 2012 roku. Z tego względu nie jest on jeszcze tak popularny jak chociażby opcje na akcje. Można jednak przypuszczać, że ten typ płacy zyska na znaczeniu w przyszłości, co poprawi jakość informacji ujawnianych przez banki.

Słowa kluczowe: akcje fantomowe, polityka wynagradzania, sektor bankowy, nadzór korporacyjny, wynagrodzenie zmienne.

Summary: The ineffective executive compensation policy and excessive risk taking by managers in companies in the banking sector have been considered the main source of the outbreak of the recent financial crisis. These conclusions have led to new regulations which encourage companies to make executive remuneration dependent on the performance of the company in the long term, through the deferred portion of the salary. For this purpose a number of different financial instruments can be used, such as stocks, options and restricted stock, or increasingly used phantom stock plan. Phantom stock is a kind of compensation scheme which entitles its holder to receive a cash payment at a designated time in the future. Thanks to the fact that the amount of payment is linked mostly to the share price, the company can be confident that the actions of top executives will be aimed at achieving good performance over a long period of time. Moreover, this type of remuneration, compared to shares or stock options, does not necessitate the increase of the share capital since employees do not receive actual shares. Owing to these advantages phantom stock plans may become one of the basic elements of variable remuneration. This paper examines whether the Polish public banks use phantom stock plans to remunerate managers and to what extent the banks listed on the Warsaw Stock Exchange use phantom stock plans and what information about them they reveal. The analysis showed little interest in phantom stock plans which can be explained by the fact that the Polish public banks only since 2012 have been required to pay managers also through deferred variable remuneration. Some banks may be only in the process of introducing such plans, and therefore decided not to disclose details. For example Alior Bank, ING and PKO BP, have only mentioned this instrument of remuneration in their reports. In addition, ten banks had other long-term incentive plans which could discourage them from using this form of remuneration. Phantom stock plans as part of the variable remuneration of top executives in the Polish banking sector can be considered a new idea, taking into account the fact that the first information about their use appeared only in 2012. For this reason, it is not yet as popular as stock options. However, it can be assumed that this type of remuneration will gain in importance in the future which will improve the quality of bank disclosures.

Keywords: phantom stocks, remuneration policy, banking sector, corporate governance, variable remuneration. 
Agata Wieczorek

\author{
Najpiękniejsza rzecza, jakiej możemy \\ doświadczyć, jest oczarowanie \\ tajemnica. Jest to uczucie, które stoi \\ u kolebki prawdziwej sztuki i prawdziwej \\ nauki. Ten, kto go nie zna i nie potrafi \\ się dziwić, nie potrafi doznawać \\ zachwytu, jest martwy, niczym \\ zdmuchnięta świeczka.
}

Albert Einstein

\title{
1. Wstęp
}

Kryzys finansowy z 2008 r. pokazał, jakie mogą być skutki nieefektywnej polityki wynagradzania. Zachęcanie menedżerów do skupiania się na wynikach w krótkim horyzoncie czasowym przyczynia się do podejmowania nadmiernego ryzyka, co może negatywnie wpływać na wartość spółki w dłuższej perspektywie. Dlatego też nowe regulacje prawne i środowiskowe kładą nacisk na powiązanie wynagrodzenia $\mathrm{z}$ wynikami przedsiębiorstwa $\mathrm{w}$ długim okresie poprzez odroczenie części wynagrodzenia kadry kierowniczej najwyższego szczebla. Do tego celu mogą być wykorzystywane różnego typu instrumenty finansowe, takie jak akcje, opcje na akcje czy też coraz powszechniej stosowane akcje fantomowe.

Artykuł ma na celu prezentację jednego z instrumentów polityki wynagradzania kadry kierowniczej najwyższego szczebla, jakim są akcje fantomowe. Przedstawiona zostanie główna charakterystyka akcji fantomowych, a na próbie polskich banków notowanych na Giełdzie Papierów Wartościowych w Warszawie zostanie zbadane, czy wykorzystują one akcje fantomowe oraz jakie informacje na ich temat ujawniaja.

\section{Akcje fantomowe jako narzędzie polityki wynagradzania}

Podstawowymi celami polityki zmiennych składników wynagrodzenia jest motywowanie menedżerów do działań zgodnych $\mathrm{z}$ długookresowymi celami przedsiębiorstwa. Jednym z narzędzi, które miały służyć do realizacji tego celu, są akcje. W większości przypadków kadra kierownicza najwyższego szczebla, która jest wynagradzana w ten sposób, sprzedaje posiadane akcje zaraz po tym, jak je otrzyma, bądź też po obowiązującym okresie, w którym musi je trzymać. Sprzedając akcje na rynku, kadra kierownicza może się przyczynić do rozproszenia akcjonariatu, co jest źle postrzegane przez obecnych akcjonariuszy. Powoduje to, że spółki przestają być zainteresowane tego typu wynagrodzeniem, gdyż podstawowe cele, dla jakich jest ono stosowane, nie są realizowane. $Z$ tego powodu wykorzystanie w polityce zmiennych składników wynagrodzeń osób zarządzających akcji fantomowych wydaje się interesującym rozwiązaniem. 
Akcje fantomowe to rodzaj planu wynagradzania, który uprawnia do otrzymania środków pieniężnych w pewnym momencie w przyszłości, zazwyczaj jako udział w otrzymanych wpływach ze sprzedaży spółki [King 2014]. Kwota otrzymanej w ten sposób gotówki najczęściej jest powiązana z wartością akcji spółki bądź aprecjacji wartości akcji po dacie przyznania akcji fantomowych.

Akcje fantomowe można przyrównać do premii gotówkowej, przy czym wynagrodzenie $\mathrm{z}$ tego tytułu jest znacznie wyższe niż w przypadku bonusów rocznych. Otrzymanie wypłaty $z$ tytułu posiadania akcji fantomowych wiąże się ze spełnieniem określonych warunków. Najczęściej jest to związane z koniecznością pozostania w stosunku pracy z przedsiębiorstwem. Posiadanie tego typu instrumentów finansowych przez kadrę kierowniczą najwyższego szczebla umożliwia realizację celu polityki zmiennych składników wynagrodzeń, jakim jest zwiększenie lojalności pracownika w stosunku do spółki. Dodatkowo uczestnicy programu zawierającego akcje fantomowe nie otrzymują żadnych akcji, tylko ich ekwiwalent pieniężny, co pozwala na utrzymanie dotychczasowego stopnia koncentracji akcjonariatu.

Akcje fantomowe są wykorzystywane w spółkach $\mathrm{z}$ wielu różnych powodów. Wśród nich można wymienić następujące [Phantom stock... 2014]:

- właściciele spółki chcą podzielić wartość ekonomiczną kapitału własnego, ale nie sam kapitał (wartość ekonomiczna kapitału jest dzielona zarówno na akcje rzeczywiste, jak i fantomowe, natomiast sam kapitał dzielony jest jedynie na akcje rzeczywiste),

- spółka nie może zaoferować konwencjonalnych rodzajów planów partycypacji we własności z powodu ograniczeń korporacyjnych, dotyczących spółek z ograniczoną odpowiedzialnością, spółek partnerskich, spółek jednoosobowych bądź spółek, w których jeden akcjonariusz ma 100\% udziału we własności,

- spółka ma już tradycyjny plan partycypacji we własności, ale chce zapewnić dodatkowe zachęty kapitałowe, bez przyznawania samych akcji, wybranym pracownikom,

- kierownictwo spółki rozważało inne plany, ale uznało, że ich przepisy są zbyt restrykcyjne lub koszty ich wdrożenia są zbyt wysokie,

- spółka jest oddziałem innego przedsiębiorstwa, ale może stworzyć miernik jej wartości majątku i chce, by pracownicy mieli w tym udział, mimo że nie ma rzeczywistych akcji,

- jednostka jest organizacją non-profit lub instytucją sektora publicznego, mogącą jednak stworzyć jakiś rodzaj miernika, który symuluje wzrost kapitału własnego, który będzie mógł być wykorzystany jako podstawa do wypłaty premii dla pracownika.

Akcje fantomowe mogą być stosowane na wiele różnych sposobów, nie tylko jako podejście, które nie narusza struktury własności w długoterminowych programach motywacyjnych. Można je także wykorzystać z innymi rodzajami wynagrodzenia. Przykładowo mogą to być [Whittlesey 1994, s. 53-54]: 
- niekwalifikowane programy wynagrodzenia odroczonego (nonqualified deferred compensation plans) - spółka może zezwolić pracownikowi na odroczenie otrzymania wynagrodzenia gotówkowego - wynagrodzenia zasadniczego lub/i premii - aż do pewnego momentu w przyszłości, takiego jak przejście na emeryturę. Odroczona kwota może być inwestowana w akcje fantomowe. Powiązanie wzrostu odroczonych środków z wynikami spółki może stworzyć dobrowolny program akcji fantomowych;

- uzupełniające programy emerytalne (supplemental retirement plans) - ustanawiając program emerytalny dla wybranych, kluczowych dla spółki pracowników, można wykorzystać akcje fantomowe, aby określić wielkość wkładu pracodawcy jako podstawy wzrostu wartości funduszu w okresie odroczenia. Spółka może ustalić potencjalny zakres wkładu rocznie, wraz z rzeczywistą kwotą określoną przez wyniki finansowe. Kwoty te są następnie inwestowane w akcje fantomowe, z ostateczną wartością odroczonego funduszu powiązanego z wartością akcji fantomowych;

- roczne programy motywacyjne (annual incentive plans) - spółka może zażądać, by odroczone płatności z rocznego programu motywacyjnego zostały zainwestowane w akcje fantomowe. W spółce połowa rocznej premii może być odroczona w postaci akcji fantomowych, a pracownik może inwestować część lub całość pozostałej kwoty także w akcje fantomowe. Taka metoda jest zastępowana przez coraz bardziej popularne praktyki w spółkach publicznych wypłacania całości lub części rocznej premii w postaci akcji lub akcji z ograniczonym prawem sprzedaży;

- programy zakupu akcji (stock purchase plans) - spółka może zezwolić lub wymagać zakupu akcji fantomowych, aby zapewnić sobie zaangażowanie poszczególnych pracowników, a nie po to, by stworzyć okazję do zysku bez ryzyka. Kluczowym pracownikom mogą być oferowane okazje do nabycia akcji fantomowych za gotówkę bądź też spółka może udzielić pożyczki lub zaoferować program płatności w ratach. Ma to zapewnić, by kluczowa grupa pracowników miała okazję do zostania „właścicielami fantomowymi”, z możliwością zostania prawdziwymi właścicielami, jeśli cele spółki się zmienią.

Wykorzystanie przez przedsiębiorstwo akcji fantomowych może przynieść wiele korzyści zarówno pracownikom, jak i samej spółce. Jedną z nich jest uniknięcie rozwodnienia akcjonariatu przez nowych akcjonariuszy. Nie zmienią one zatem udziałów we własności obecnych akcjonariuszy i ich prawa kontroli [Dai, Zhou 2015, s. 47]. Dodatkowo pozwoli to uchronić spółkę przed pojawieniem się konfliktu interesów na linii akcjonariusz dominujący-akcjonariusze mniejszościowi. Obecni właściciele akcji zaś nie będą narażeni na obniżenie wartości kapitału, co zmniejszyłoby ich zyski.

Kolejną korzyścią jest wzrost motywacji kadry kierowniczej najwyższego szczebla do osiagania lepszych wyników finansowych spółki. Wynika to z tego, że programy oparte na pochodnych instrumentach finansowych odnoszą się do wartości akcji/ 
udziałów spółki lub wyników spółki. Można zatem powiedzieć, że nagrody pracowników są powiązane z zyskiem akcjonariuszy. Dzięki wykorzystaniu wieloletnich okresów oceny akcje te dodatkowo zapewniają miernik oparty na wynikach, który można wykorzystać przy ocenie kluczowych pracowników. Ponieważ płatność zostaje odroczona do czasu osiagnięcia wyników działalności spółki tworzących wartość ekonomiczną niezbędną do wypłaty nagrody, można powiedzieć, że spółka wykorzystuje podejście samofinansowania [Whittlesey 1994, s. 55].

Dodatkowo programy takie sprzyjają zatrzymaniu najlepszych osób w organizacji ze względu na długoterminową motywację i atrakcyjność finansową [Charchulska-Pietrzyk, Narkiewicz-Tarłowska 2014]. Stosowanie akcji fantomowych daje pracownikom szanse na uzyskanie korzyści znacznie przekraczających tradycyjne formy wynagrodzeń, takie jak płaca zasadnicza czy premia roczna. Dodatkową wartością akcji fantomowych jest to, iż ich wykorzystanie nie wiąże się ze zwiększeniem wynagrodzenia podstawowego [Welsh 2012]. Ponieważ ten instrument finansowy jest jedynie pewnym odpowiednikiem akcji, nie pociaga za sobą konieczności zakupu przez pracowników akcji lub opcji na akcje, które wymagają nakładów pieniężnych. Co więcej, dzięki temu, że akcje fantomowe są akcjami wirtualnymi, uczestnicy programu nie muszą czekać na wzrost ceny na rynku akcji w celu uzyskania zysków z ich sprzedaży.

Należy także zwrócić uwagę na korzyści związane z aspektami podatkowymi. Wynagrodzenie z tytułu akcji fantomowych w pewnych okolicznościach może być opodatkowane jak dochody kapitałowe, a nie jak dochody ze stosunku pracy. Pozwala to zmniejszyć obciążenie podatkowe tym pracownikom, którzy przekroczyli próg podatkowy. Dodatkowo dochody takie mogą nie podlegać składkom na ubezpieczenia społeczne i zdrowotne [Charchulska-Pietrzyk, Narkiewicz-Tarłowska 2014].

Wykorzystanie akcji fantomowych przynosi wiele korzyści, lecz nie można także zapominać o zagrożeniach. Wiele spółek giełdowych woli uniknąć tego typu instrumentów finansowych z różnych powodów - potencjalnych problemów związanych ze sposobem ujawniania skutków finansowych tego typu instrumentów, a także z możliwością, że spółka może być krytykowana za wypłatę nagród głównie za pomocą gotówki (ze względu na to, że akcje fantomowe są rozliczane za pomocą gotówki, premia roczna i dodatkowe korzyści również są wypłacane w formie pieniężnej, ich suma daje często znaczącą kwotę), w przypadku gdy jej akcje mają dużą amplitudę wahań, jeśli chodzi o jej ceny [Ellis 2014].

Rozliczenie kosztów wynikających z opłacenia akcji fantomowych może znacząco przewyższać zyski ze stosowania tego instrumentu finansowego. Co więcej, wielkość tych kosztów może nie być do końca przewidywalna w momencie tworzenia programu. Należy także podkreślić, że odliczenie od podatku jest odroczone, dopóki nagroda nie zostanie wypłacona, co w początkowej fazie programu generuje znaczne koszty dla spółki. 
Innym zagrożeniem związanym ze stosowaniem akcji fantomowych jest obawa, iż pracownicy nie będą wiedzieli, co faktycznie dostają. Nie otrzymują oni rzeczywistych praw własności, co może budzić w uczestnikach programu podejrzenie, czy proponowany program jest uczciwy.

W momencie, gdy okres oceny jest stały, pracownicy nie mają kontroli nad terminami płatności. Oznacza to, że nie będą oni mogli sami decydować, kiedy chcą otrzymać wynagrodzenie z tytułu posiadania akcji fantomowych. Może to również powodować, iż wydatki niezbędne do przyznania nagrody pieniężnej pojawią się wtedy, gdy spółka będzie mieć problemy finansowe.

\section{Akcje fantomowe w bankach publicznych w Polsce - wyniki badań}

W polskim sektorze bankowym obowiązek stosowania polityki zmiennych składników wynagrodzeń pojawił się dopiero w 2012 r., po wejściu w życie Uchwały Komisji Nadzoru Finansowego z 4 października 2011 r. [Uchwała nr 258/2011...]. Banki mają możliwość wyboru stosowania różnych instrumentów finansowych (np. akcji, opcji na akcje, akcji fantomowych) do wynagradzania kadry kierowniczej najwyższego szczebla. $Z$ tego powodu interesujące wydaje się pytanie, czy banki publiczne w Polsce wykorzystują akcje fantomowe jako składnik płacy menedżerów. Analiza objęła 14 banków notowanych na Giełdzie Papierów Wartościowych w Warszawie w latach 2012-2013. Dane niezbędne do badania zostały zebrane na podstawie raportów rocznych i raportów o adekwatności kapitałowej, dostępnych na stronach internetowych banków.

Część odroczona wynagrodzenia osób zarząadzających może być wypłacana w różny sposób. Najczęściej banki decydują się na wykorzystanie akcji spółki lub opcji na akcje w ramach długoterminowych programów motywacyjnych (Long-Term Incentive Plans - TLIP). Jednakże inną możliwością, która nie wiąże się z koniecznością rozproszenia akcjonariatu, jest zastosowanie akcji fantomowych. W tabeli 1 zostało pokazane, czy polskie banki publiczne zdecydowały się posłużyć akcjami fantomowymi przy wynagradzaniu kadry kierowniczej najwyższego szczebla.

Jak widać, 9 banków w swoich raportach rocznych informuje o wykorzystaniu akcji fantomowych jako jednego z elementów polityki zmiennych składników wynagrodzenia. Alior Bank nie rozpoczął jeszcze takiego programu, informując jedynie, iż uczestnikom programu zostaną przydzielone akcje fantomowe według formuły: wynagrodzenie zmienne podzielone przez cenę jednej akcji fantomowej, które następnie będą spieniężane i wypłacane w czterech transzach. BOŚ w roku 2013 poinformował jedynie, że część przyznana $w$ akcjach fantomowych zostanie wypłacona w I kwartale 2014 r. w formie świadczenia pieniężnego, a kwoty odroczone zostaną wypłacone, po ich przyznaniu, w trzech kolejnych latach, to jest w 2014, 
Tabela 1. Wykorzystanie długoterminowych programów motywacyjnych jako elementu polityki zmiennych składników wynagrodzenia w bankach publicznych w latach 2012-2013

\begin{tabular}{|l|c|c|c|c|}
\hline \multirow{2}{*}{} & \multicolumn{2}{|c|}{2012} & \multicolumn{2}{c|}{2013} \\
\cline { 2 - 5 } & akcje fantomowe & inne LTIP & akcje fantomowe & inne LTIP \\
\hline Alior Bank & TAK & TAK & TAK & TAK \\
\hline Bank BPH & TAK & TAK & TAK & TAK \\
\hline Bank Handlowy & TAK & TAK & TAK & TAK \\
\hline BGŻ & TAK & NIE & TAK & NIE \\
\hline BOŚ & NIE & TAK & NIE & TAK \\
\hline BZ WBK & NIE & TAK & NIE & TAK \\
\hline ING & TAK & TAK & NIE & TAK \\
\hline MBank & NIE & TAK & NIE & TAK \\
\hline Millennium & TAK & NIE & TAK & NIE \\
\hline Noble Bank & TAK & TAK & TAK & TAK \\
\hline Nordea Bank & TAK & TAK & TAK & TAK \\
\hline Paribas Fortis & NIE & NIE & NIE & NIE \\
\hline Pekao SA & TAK & TAK & TAK & TAK \\
\hline PKO BP & TAK & NIE & TAK & NIE \\
\hline
\end{tabular}

Źródło: opracowanie własne na podstawie raportów rocznych banków publicznych.

2015 i 2016 r. w równych częściach. ING podaje jedynie informacje, że część wynagrodzenia przyznana jest $\mathrm{w}$ formie akcji fantomowych, uprawniających do otrzymania świadczenia pieniężnego, do których zastosowany jest roczny termin przetrzymania akcji. Bank PKO BP informuje, że składnik wynagrodzenia $\mathrm{w}$ formie instrumentu finansowego jest przeliczany na akcje fantomowe po przyznaniu danego składnika, a następnie, po okresie retencyjnym i okresie odroczenia, akcje są przeliczane na gotówkę. Pozostałe banki nie zdecydowały się na takie rozwiązanie bądź też nie ujawniły takich informacji.

Badanie wykazało, że 4 banki, które nie zdecydowały się na wprowadzenie akcji fantomowych, posiadały inne długoterminowe programy motywacyjne. Bank Millennium, BGŻ oraz PKO BP wykorzystują jedynie wynagrodzenie zmienne w postaci akcji fantomowych. Natomiast Paribas Fortis nie posiada żadnego długoterminowego programu motywacyjnego. Pozostałe banki zaś zdecydowały się zarówno na utworzenie LTIP, jak i wykorzystanie akcji fantomowych. Wyniki te mogą świadczyć o tym, iż polskie banki publiczne wykorzystują różne metody odroczenia wynagrodzenia, przy czym akcje fantomowe nie są podstawowym elementem długoterminowych programów motywacyjnych.

Dalsza część analizy została oparta na bankach publicznych wykorzystujących ten instrument motywacyjny kadry kierowniczej.

Tak jak w przypadku innych instrumentów finansowych wykorzystywanych do wynagrodzenia odroczonego, akcje fantomowe muszą mieć termin nabycia upraw- 
nień. Mówi on, od kiedy uczestnicy programu mają prawo do otrzymania akcji fantomowych. Kolejną istotną datą związaną z programem motywacyjnym opartym na akcjach fantomowych jest termin zapadalności. Jest to ostateczny termin, w którym spółka zobowiązała się wypłacić nagrodę z tytułu posiadania akcji fantomowych, niezależnie od harmonogramu spłat. Okres między tymi dwoma datami pozwala określić, czy akcje fantomowe faktycznie służą do zmotywowania menedżerów do osiagania lepszych wyników banku w długim okresie. Tabela 2 pokazuje, jaki jest okres między datą nabycia uprawnień a datą zapadalności.

Tabela 2. Okres między datą nabycia uprawnień a datą zapadalności akcji fantomowych

\begin{tabular}{|c|c|c|}
\hline & 2012 & 2013 \\
\hline Alior Bank & \multicolumn{2}{|c|}{ brak danych } \\
\hline Bank BPH & \multicolumn{2}{|c|}{3 lata } \\
\hline Bank Handlowy & \multicolumn{2}{|c|}{6 miesięcy } \\
\hline BGŻ & \multicolumn{2}{|c|}{4 lata } \\
\hline ING & \multicolumn{2}{|c|}{ brak danych } \\
\hline Millennium & 4,5 roku & 4 lata \\
\hline Noble Bank & \multicolumn{2}{|c|}{$\begin{array}{l}10 \% \text { wynagrodzenia zmiennego }-1 \text { rok } \\
40 \% \text { wynagrodzenia zmiennego }-4 \text { lata }\end{array}$} \\
\hline Nordea Bank & \multicolumn{2}{|c|}{$\begin{array}{c}5 \text { lat - zarząd i wyższa kadra zarządzająca } \\
3 \text { lata - pozostała kadra zarządzająca }\end{array}$} \\
\hline Pekao SA & \multicolumn{2}{|c|}{ 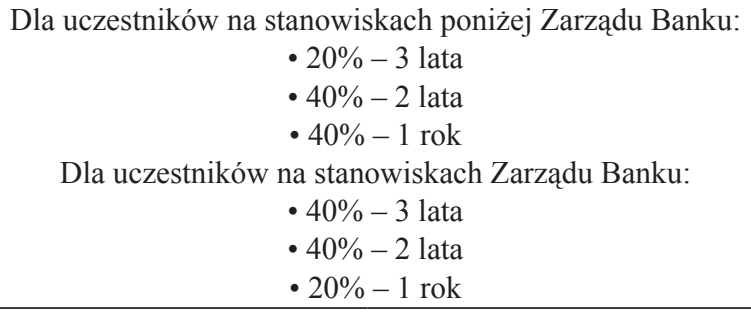 } \\
\hline PKO BP & \multicolumn{2}{|c|}{ brak danych } \\
\hline
\end{tabular}

Źródło: opracowanie własne na podstawie raportów rocznych.

Informacje na temat daty nabycia uprawnień i daty zapadalności ujawniła większość badanych banków (poza Alior Bankiem, ING i PKO BP), co pozwoliło ustalić okres, w którym posiadacze akcji fantomowych moga je zrealizować. Bank Handlowy ustalił ten okres na 6 miesięcy. Oznacza to, że posiadacze akcji fantomowych bardzo szybko powinni je zrealizować. Nie motywuje to zatem uczestników programu do działań zgodnych z długookresowymi celami banku. Akcje fantomowe można tu raczej potraktować jako formę premii rocznej. Noble Bank określił, że akcje fantomowe będą stanowić 50\% wynagrodzenia zmiennego, oraz wyznaczył dwa przedziały okresu ich realizacji. 10\% wynagrodzenia zmiennego w postaci akcji fantomowych menedżerowie mogą zrealizować w ciagu roku, $40 \%$ zaś w ciagu 4 lat. Takie rozwiązanie pozwala na zwrócenie uwagi uczestników programu na uwzględ- 
nianie w swoich działaniach zarówno krótkiego, jak i długiego horyzontu czasowego. Może to zatem przyczynić się do ciągłego podnoszenia wartości banku. Podobne podejście zastosował bank Pekao SA, przy czym są tu różne proporcje dla uczestników na stanowiskach poniżej zarządu banku i dla samych członków zarządu. W przypadku tych pierwszych realizacja $20 \%$ akcji fantomowych może nastapić w ciagu 3 lat oraz po $40 \%$ w ciagu 2 lat i jednego roku. Członkowie zarządu mają odwrotna proporcję, to znaczy po $40 \%$ przyznanych akcji fantomowych mogą zrealizować w ciagu 3 i 2 lat, $20 \%$ zaś w ciągu roku. Taki podział wynagrodzenia $\mathrm{w}$ formie akcji fantomowych dla obu grup uczestników programu świadczy o tym, iż dla banku Pekao SA ważniejsze jest, aby członkowie zarządu zwracali szczególną uwagę na wyniki długookresowe. Podobnie jak Pekao SA, Nordea Bank także podzielił uczestników programu na dwie grupy i wyznaczył im różne okresy, w jakich mogą zrealizować przyznane akcje fantomowe. Zarząd i wyższa kadra kierownicza mogą to zrobić w ciagu 5 lat od daty nabycia uprawnień. Pozostała kadra zarządzająca ma na to 3 lata.

Przedstawione wyniki potwierdzaja podstawowy cel wykorzystania tego typu instrumentów finansowych, a mianowicie dbanie o interesy banku w długim horyzoncie czasowym. Badane banki, dając uczestnikom programu możliwość zrealizowania przyznanych akcji fantomowych w ciagu kilku lat, motywują ich do podnoszenia wartości spółki w tym okresie.

Przyznanie uczestnikom programu jakichkolwiek instrumentów finansowych wiąże się ze spełnieniem pewnych warunków. W tabeli 3 przedstawiono, jakie kryteria przyznawania akcji ustaliły polskie banki publiczne.

Większość banków (poza Nordea Bankiem, Alior Bankiem, ING i PKO BP) ustaliła, że jednym z warunków nabycia uprawnień są wyniki banku, przy czym jedynie Noble Bank wyszczególnił, że chodzi o zysk skonsolidowany. Pięć banków stwierdziło, że nabycie uprawnień do zmiennych składników wynagrodzeń w postaci akcji fantomowych będzie zależeć od oceny indywidualnych wyników pracy danej osoby. Żaden bank jednak nie określił, co przez to pojęcie rozumie. Również pięć banków jako jeden z warunków nabycia uprawnień wyznaczyło konieczność ciągłości zatrudnienia. Bank BGŻ dodatkowo uznał, że analiza wystapienia sytuacji mogących mieć wpływ na obniżenie odroczonej części wynagrodzenia zmiennego także zostanie uwzględniona przy wydawaniu uprawnień do akcji fantomowych. Noble Bank zaś określił także kryterium niefinansowe, do którego zaliczył przyjęcie przez Walne Zgromadzenie Akcjonariuszy sprawozdania finansowego z działalności spółki. Nordea Bank jako jedyna spółka nie wyznaczył żadnych warunków, które muszą spełnić uczestnicy programu, by nabyć akcje. Określił natomiast warunki wykluczające lub zmniejszające wypłatę wynagrodzenia. Zaliczył do nich poniesienie przez bank skorygowanej straty operacyjnej oraz naruszenie przez bank wymogów kapitałowych. Mimo że wszystkie banki określiły warunki nabycia uprawnień (poza Nordea Bankiem), jedynie warunek dotyczący konieczności pozostania w stosunku pracy z bankiem został precyzyjnie sformułowany. Pozostałe wymagania nie zostały 
Tabela 3. Warunki nabycia uprawnień do akcji fantomowych

\begin{tabular}{|c|c|c|}
\hline & 2012 & 2013 \\
\hline Alior Bank & \multicolumn{2}{|c|}{ brak danych } \\
\hline Bank BPH & $\begin{array}{l}\text { - Spełnienie warunków dotyczących } \\
\text { zatrudnienia w Banku w roku } 2012 \\
\text { - Wyniki Banku } \\
\text { - Indywidualne wyniki pracy }\end{array}$ & $\begin{aligned} \text { - Spełnienie warunków dotyczących } \\
\\
\text { zatrudnienia w Banku w roku } 2013 \\
\text { - Wyniki Banku } \\
\text { - Indywidualne wyniki pracy }\end{aligned}$ \\
\hline $\begin{array}{l}\text { Bank } \\
\text { Handlowy }\end{array}$ & $\begin{aligned} \text { - Spełnienie warunków dotyczących } \\
\text { zatrudnienia w Grupie w latach } \\
\\
\text { 2013, } 2014 \text { i } 2015 \\
\text { - Wyniki Banku } \\
\text { - Indywidualne wyniki pracy }\end{aligned}$ & $\begin{array}{l}\text { - Spełnienie warunków dotyczących } \\
\text { wyników Banku } \\
\text { - indywidualne wyniki pracy } \\
\text { - Zatrudnienie w Grupie w latach } 2014, \\
\\
\text { 2015 i } 2016 \text { w odniesieniu do nagrody } \\
\text { z } 2014 \text { roku }\end{array}$ \\
\hline BGŻ & \multicolumn{2}{|c|}{$\begin{array}{l}\text { - Ocena indywidualnych wyników pracy } \\
\text { - Wyniki finansowe Banku } \\
\text { - Analiza wystappienia sytuacji mogących mieć wpływ na obniżenie odroczonej } \\
\text { części wynagrodzenia zmiennego } \\
\text { - Spełnienie warunków dotyczących zatrudnienia w Banku }\end{array}$} \\
\hline ING & \multicolumn{2}{|c|}{ brak danych } \\
\hline Millennium & $\begin{array}{l}\text { - Spełnienie warunków dotyczących } \\
\text { zatrudnienia w Grupie w roku } 2012 \\
\text { - Wyniki Grupy } \\
\text { - Indywidualne wyniki pracy }\end{array}$ & $\begin{aligned} \text { - Spełnienie warunków dotyczących } \\
\\
\text { zatrudnienia w Grupie w roku } 2013 \\
\text { - Wyniki jednostek Grupy } \\
\text { - Indywidualne wyniki pracy }\end{aligned}$ \\
\hline Noble Bank & \multicolumn{2}{|c|}{$\begin{array}{l}\text { - Wypłata jest uzależniona od wyników pracy danej osoby zajmującej stanowisko } \\
\text { kierownicze objęte polityką w okresie oceny oraz uwzględnia ryzyko Banku } \\
\text { - Głównym kryterium finansowym determinującym wysokość wypłacanych } \\
\text { zmiennych składników wynagrodzeń jest zysk skonsolidowany } \\
\text { - Głównym kryterium niefinansowym jest przyjęcie przez Walne Zgromadzenie } \\
\text { Akcjonariuszy sprawozdania finansowego z działalności Spółki }\end{array}$} \\
\hline Nordea Bank & brak & brak \\
\hline Pekao SA & \multicolumn{2}{|c|}{$\begin{array}{l}\text { - Ocena zgodności } \\
\text { - Ciągłość zatrudnienia } \\
\text { - Spełnienie warunku opartego na wynikach finansowych Banku za zadany okres }\end{array}$} \\
\hline PKO BP & \multicolumn{2}{|l|}{ brak danych } \\
\hline
\end{tabular}

Źródło: opracowanie własne na podstawie raportów rocznych.

tak jasno sprecyzowane, co nie pozwala na pełną ocenę tych warunków. Świadczy to również o dużej niechęci polskich banków publicznych do ujawniania szczegółowych informacji.

Tak jak każdy długoterminowy program motywacyjny, program oparty na akcjach fantomowych także musi zostać rozliczony. Tabela 4 przedstawia sposoby rozliczania tego typu programów przez polskie banki publiczne.

Jedynie Alior Bank, ING i PKO BP nie ujawniły szczegółów dotyczących rozliczenia programu opartego na akcjach fantomowych. Noble Bank określił, iż pro- 
Tabela 4. Sposoby rozliczenia programu

\begin{tabular}{|c|c|c|}
\hline & 2012 & 2013 \\
\hline Alior Bank & \multicolumn{2}{|l|}{ brak danych } \\
\hline Bank BPH & \multicolumn{2}{|c|}{$\begin{array}{l}\text { W dniu rozliczenia uczestnikowi zostanie wypłacona kwota środków pieniężnych } \\
\text { stanowiąca iloczyn posiadanych przez uczestnika akcji fantomowych oraz mediany } \\
\text { średnio dziennych cen akcji Banku na GPW z okresu } 90 \text { dni poprzedzających dzień } \\
\text { rozliczenia }\end{array}$} \\
\hline $\begin{array}{l}\text { Bank } \\
\text { Handlowy }\end{array}$ & \multicolumn{2}{|c|}{$\begin{array}{l}\text { W dniu rozliczenia uczestnikowi zostanie wypłacona kwota środków pieniężnych } \\
\text { stanowiąca iloczyn posiadanych przez uczestnika akcji fantomowych oraz średniej } \\
\text { arytmetycznej najniższej i najwyższej ceny akcji Banku na GPW w dniu nabycia } \\
\text { uprawnienia do nagrody. Nabycie uprawnienia będzie każdorazowo potwierdzone } \\
\text { decyzją Rady Nadzorczej w stosunku do Zarządu oraz decyzją Zarządu w stosunku } \\
\text { do pozostałych pracowników objętych Polityką }\end{array}$} \\
\hline BGŻ & \multicolumn{2}{|c|}{$\begin{array}{l}\text { W dniu rozliczenia uczestnikowi zostanie wypłacona kwota środków pieniężnych } \\
\text { stanowiąca iloczyn posiadanych przez uczestnika akcji fantomowych oraz mediany } \\
\text { średnio dziennych cen akcji Banku na GPW z okresu } 90 \text { dni poprzedzających dzień } \\
\text { rozliczenia }\end{array}$} \\
\hline ING & \multicolumn{2}{|l|}{ brak danych } \\
\hline Millen & $\begin{array}{l}\text { W dniu rozliczenia uczestnikowi zosta- } \\
\text { nie wypłacona kwota środków pienięż- } \\
\text { nych stanowiąca iloczyn posiadanych } \\
\text { przez uczestnika akcji fantomowych } \\
\text { oraz średniej arytmetycznej ceny akcji } \\
\text { Banku na GPW na zamknięcie } 10 \text { kolej- } \\
\text { nych sesji poprzedzających dzień rozli- } \\
\text { czenia }\end{array}$ & $\begin{array}{l}\text { W dniu rozliczenia uczestnikowi zostanie } \\
\text { wypłacona kwota środków pieniężnych } \\
\text { stanowiąca iloczyn posiadanych przez } \\
\text { uczestnika akcji fantomowych oraz śred- } \\
\text { niej arytmetycznej ceny akcji Banku na } \\
\text { GPW na zamknięcie } 10 \text { kolejnych sesji } \\
\text { poprzedzających dzień rozliczenia, przy } \\
\text { czym ustalana tak wartość nie może być } \\
\text { większa ani też mniejsza niż o } 20 \% \text { w sto- } \\
\text { sunku do pierwotnej wartości odroczonej } \\
\text { puli akcji. Akcje fantomowe są rozliczane } \\
\text { w } 3 \text { równych rocznych ratach, począwszy } \\
\text { od daty Komitetu Personalnego, na któ- } \\
\text { rym zostały przydzielone }\end{array}$ \\
\hline Noble & \multicolumn{2}{|c|}{$\begin{array}{l}\text { Akcje fantomowe uprawniają do otrzymania środków pieniężnych, których wysokość } \\
\text { uzależniona jest od wartości akcji Banku }\end{array}$} \\
\hline Nord & $\begin{array}{l}\text { Kwota wypłaty każdej z transz zostanie } \\
\text { obliczona jako iloczyn kwoty wynagro- } \\
\text { dzenia pierwotnie przyznanej oraz pro- } \\
\text { centowej zmiany wskaźnika TSR pomię- } \\
\text { dzy wskaźnikiem bazowym za } 2012 \text { r. a } \\
\text { wskaźnikiem za okres, którego dotyczy } \\
\text { dana transza. Rozliczenie nastapi do } 30 \\
\text { października każdego z lat trwania pro- } \\
\text { gramu }\end{array}$ & $\begin{array}{l}\text { Kwota wypłaty każdej z transz zostanie } \\
\text { obliczona jako iloczyn kwoty wynagro- } \\
\text { dzenia pierwotnie przyznanej oraz pro- } \\
\text { centowej zmiany wskaźnika TSR pomię- } \\
\text { dzy wskaźnikiem bazowym za } 2013 \text { r. } \\
\text { a wskaźnikiem za okres, którego dotyczy } \\
\text { dana transza. Rozliczenie nastapi do } 30 \\
\text { października każdego z lat trwania pro- } \\
\text { gramu }\end{array}$ \\
\hline Pekao SA & \multirow{2}{*}{\multicolumn{2}{|c|}{$\begin{array}{l}\text { W dniu nabycia uprawnień uczestnikowi zostanie wypłacona kwota środków pie- } \\
\text { niężnych stanowiąca iloczyn posiadanych przez uczestnika akcji fantomowych oraz } \\
\text { średniej arytmetycznej ceny akcji Banku na GPW w miesiącu kalendarzowym po- } \\
\text { przedzającym miesiąc wypłaty środków pieniężnych }\end{array}$}} \\
\hline PKO BP & & \\
\hline
\end{tabular}

Źródło: opracowanie własne na podstawie raportów rocznych. 
gram będzie rozliczony w formie środków pieniężnych, których wysokość uzależniona jest od wartości akcji banku. Nie podaje jednak żadnych dokładniejszych informacji. Pozostałe banki rozliczenie programu opisały nieco dokładniej. W banku BPH i BGŻ w dniu rozliczenia każdemu uczestnikowi zostanie wypłacona kwota środków pieniężnych stanowiąca iloczyn posiadanych przez uczestnika akcji fantomowych oraz mediany średnio dziennych cen akcji banku na Giełdzie Papierów Wartościowych w Warszawie z okresu 90 dni poprzedzających dzień rozliczenia. W przypadku banku Handlowego brana jest pod uwagę średnia arytmetyczna najniższej i najwyższej ceny akcji banku na warszawskiej Giełdzie Papierów Wartościowych w dniu nabycia uprawnienia do nagrody, w banku Millennium średnia arytmetyczna ceny akcji banku na GPW na zamknięcie 10 kolejnych sesji poprzedzających dzień rozliczenia, zaś w Pekao SA średnia arytmetyczna średniej ceny akcji banku na Giełdzie Papierów Wartościowych w Warszawie w miesiącu kalendarzowym poprzedzającym miesiąc wypłaty środków pieniężnych. Nordea Bank określił, że kwota wypłaty każdej z transz zostanie obliczona jako iloczyn kwoty wynagrodzenia pierwotnie przyznanej oraz procentowej zmiany wskaźnika TSR pomiędzy wskaźnikiem bazowym za 2012 rok (dla programu z 2012 roku) lub za 2013 rok (dla programu z 2013 roku) a wskaźnikiem za okres, którego dotyczy dana transza. Przy tym Nordea Bank zaznaczył, że rozliczenie nastąpi do 30 października każdego z lat trwania programu.

Należy podkreślić, że sposób rozliczenia programu we wszystkich badanych bankach jest zbliżony. Wszystkie banki wykorzystują środki pieniężne zamiast instrumentów kapitałowych, co pozwala na ograniczenie emisji nowych akcji. W większości przypadków (poza Nordea Bankiem) suma pieniędzy otrzymana przez uczestników programu zależeć będzie od ceny akcji oraz liczby posiadanych akcji fantomowych.

\section{Zakończenie}

W polskim sektorze bankowym od wielu lat kadra kierownicza najwyższego szczebla była wynagradzana w sposób konserwatywny. Znaczną część całkowitego wynagrodzenia menedżerów stanowiła płaca zasadnicza i premia roczna. Sytuację tę miała zmienić Uchwała Komisji Nadzoru Finansowego z 4 października 2011 r., która zobowiązywała banki do stosowania zmiennych składników wynagrodzenia, w tym wynagrodzenia odroczonego. Najczęściej do tego celu wykorzystywano akcje i opcje na akcje. Instrumentem finansowym, który mniej ingeruje w strukturę akcjonariatu, są akcje fantomowe.

Przeprowadzona analiza wykazała, iż tylko połowa banków notowanych na Giełdzie Papierów Wartościowych w Warszawie w swoich raportach rocznych ujawniła informacje na temat programów motywacyjnych uwzględniających akcje fantomowe. Dodatkowo jakość danych, zarówno jeśli chodzi o ich zakres, jak i szczegółowość, znacznie się różni w poszczególnych bankach. Należy jednak zaznaczyć, 
iż poziom transparentności we wszystkich badanych bankach był niesatysfakcjonujący.

Badanie wykazało, że polskie banki publiczne wykorzystują akcje fantomowe zgodnie z ich celem. Potwierdza to okres między datą nabycia uprawnień i datą zapadalności. Ponieważ są one odroczone w czasie, uczestnicy programu są zmotywowani do działań zgodnych z długookresowymi celami banków.

Udział w programie motywacyjnym wykorzystującym akcje fantomowe powinien być traktowany jako nagroda za zasługi względem spółki, dlatego też możliwość uczestnictwa w nim powinna być obłożona pewnymi warunkami. Przeprowadzona analiza wykazała, że badane banki traktują ten program w podobny sposób i nałożyły na jego uczestników zbieżne wymagania. Najczęściej powtarzającymi się były: konieczność pozostania w stosunku pracy z bankiem, indywidualne wyniki pracy oraz wyniki banku. Niestety banki nie udzieliły szczegółowych informacji, co rozumieją przez te pojęcia.

Przeprowadzone badanie wykazało ponadto, że banki notowane na Giełdzie Papierów Wartościowych w Warszawie rozliczają program motywacyjny oparty na akcjach fantomowych za pomocą środków pieniężnych, mnożąc liczbę przyznanych akcji i cenę akcji.

Tak niewielkie zainteresowanie akcjami fantomowymi można thumaczyć tym, że polskie banki publiczne dopiero od 2012 roku są zobowiązane wynagradzać menedżerów również za pomocą wynagrodzenia zmiennego odroczonego. W związku z tym część banków może być dopiero $\mathrm{w}$ trakcie wprowadzania takiego programu, przez co nie zdecydowała się na ujawnianie szczegółowych informacji. Przykładem mogą być Alior Bank, ING i PKO BP, które jedynie wspomniały w swoich raportach o tym instrumencie wynagradzania. Dodatkowo dziesięć banków posiadało inne długoterminowe programy motywacyjne, co mogło zniechęcić je do korzystania również z tej formy wynagrodzenia.

Akcje fantomowe jako element zmiennego wynagrodzenia kadry kierowniczej najwyższego szczebla w polskim sektorze bankowym można uznać za nowy pomysł, biorąc pod uwagę fakt, iż pierwsze informacje o ich wykorzystaniu pojawiły się dopiero w 2012 roku. Z tego względu nie jest on jeszcze tak popularny jak chociażby opcje na akcje. Można jednak przypuszczać, że ten typ płacy zyska na znaczeniu w przyszłości, co poprawi jakość informacji ujawnianych przez banki.

\section{Literatura}

Charchulska-Pietrzyk J., Narkiewicz-Tarłowska J., Programy motywacyjne oparte na pochodnych instrumentach finansowych, http://www.miesiecznik-benefit.pl/index.php?wiad=952, stan na dzień 17.09.2014.

Dai L., Zhou Q., 2015, The study on incentive mode design of pay-through phantom equity, Journal of Human Resource and Sustainability Studies, 3.

King D., Why phantom stock can be better than real stock, http://www.forbes.com/sites/dking/2013/ 10/15/why-phantom-stock-can-be-better-than-real-stock/, stan na dzień 17.09.2014. 
Phantom stock and stock appreciation rights (SARs), http://www.nceo.org/articles/phantom-stock-appreciation-rights-sars, stan na dzień 17.09.2014.

Uchwała nr 258/2011 Komisji Nadzoru Finansowego z dnia 4 października 2011 r. w sprawie szczegółowych zasad funkcjonowania systemu zarządzania ryzykiem i systemu kontroli wewnętrznej oraz szczegółowych warunków szacowania przez banki kapitału wewnętrznego i dokonywania przeglądów procesu szacowania i utrzymywania kapitału wewnętrznego oraz zasad ustalania polityki zmiennych składników wynagrodzeń osób zajmujących stanowiska kierownicze w banku.

Welsh T.J., 2012, Gains from phantom stock plans, Construction Accounting and Taxation, March/ April.

Whittlesey F.E., 1994, Expanding the phantom stock concept, Compensation \& Benefits Review, November/December, s. 53-54. 